\title{
PERAN ORANG TUA DALAM MEMOTIVASI ANAK UNTUK MENGIKUTI PEMBELAJARAN E-LEARNING (ONLINE) DALAM MENINGKATKAN MINAT BACA PADA PROGRAM KESETARAAN PAKET C DI PKBM SRIKANDI
}

\author{
Mahlusi Lismayanti ${ }^{1}$, Sri Nurhayati ${ }^{2}$, Tita Rosita ${ }^{3}$ \\ 1,2,3 Program Studi Pendidikan Masyarakat, Cimahi, Jawa Barat, Indonesia.

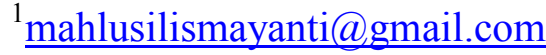

\begin{abstract}
This study aims to find out Planning, implementation and the results of parents in motivating children to participate in e-learning learning (online) in order to increase interest in reading in the Equality Program Package $\mathrm{C}$ at Srikandi Cimahi City PKBM. This research was conducted at PKBM SRIKANDI Cimahi City, using a qualitative descriptive approach. The subjects of this study were one teacher, and three students. Data collection is done using the method of observation, interviews, and documentation. Data analysis techniques used include: data collection, data reduction, data presentation, and drawing conclusions / verification. The results of this study are the role of parents in motivating children to participate in e-learning learning (online) starting with the process: 1) Program planning, starting from formulating learning goals that are tailored to the needs of students, 2) Implementing programs that refer to the needs of students, consisting from the preliminary, core, and closing activities, and 3) Program Oversight covers the process of implementing monitoring, as well as program oversight reports. Researchers give advice: Firstly, managers and teachers should add insight in the field of e-learning learning to parents, so that the process of parental roles is more optimal, both students should further enhance the spirit of learning in order to get adequate education provision.
\end{abstract}

Received: April, 2021; Accepted: Mei, 2021

Keywords: Learning E-Learning, Motivation, Parents

\begin{abstract}
Abstrak
Penelitian ini bertujuan untuk mengetahui perencanan, pelaksanaan dan hasil orang tua dalam memotivasi anak untuk mengikuti pembelajaran e-learning (online) dalam rangka meningkatkan Minat Baca pada Program Kesetaraan Paket C di PKBM Srikandi Kota Cimahi. Penelitian ini menggunakan pendekatan deskriptif kualitatif. Subjek penelitian ini adalah satu orang Guru, dan tiga orang peserta didik. Pengumpulan data yang dilakukan menggunakan metode observasi, wawancara, dan dokumentasi. Teknik analisis data yang digunakan meliputi: Pengumpulan data, Reduksi data, Penyajian data, dan penarikan kesimpulan/verifikasi. Hasil penelitian ini ialah peran orang tua dalam memotivasi anak untuk mengikuti pembelajaran e-learning (online) dimulai dengan proses: 1) Perencanaan program, dimulai dari merumuskan tujuan pembelajaran yang disesuaikan dengan kebutuhan peserta didik, 2) pelaksanaan program yang mengacu kepada kebutuan peserta didik, terdiri dari kegiatan pendahuluan, inti, dan penutup, dan 3) Pengawasan program meliputi proses pelaksanaan monitoring, serta laporan prngawasan program. Peneliti memberikan saran: perta Pengelola dan Guru hendaknya menambah wawasan dibidang pembelajaran e-learning kepada orang tua, agar proses peran orang tua lebih optimal, kedua peserta didik hendaknya lebih mempertinggi semangat belajar agar mendapat bekal pendidikan yang memadai.
\end{abstract}

Kata Kunci : Pembelajaran e-learning, motivasi, Orang Tua

How to Cite: Lismayanti, M., Nurhayati, S., \& Rosita, T. (2020). Peran Orang Tua dalam Memotivasi Anak untuk Mengikuti Pembelajaran E-Learning (Online) dalam Rangka Meningkatkan Minat Baca pada Program Kesetaraan Paket C. Comm-Edu (Community 
Education Journal), 4(2), 38-45.

\section{PENDAHULUAN}

Perhatian utama dalam pendidikan ditujukan kepada anak didik. Setiap aspek pelayanan pendidikan diperuntukkan bagi terwujudnya, aktivitas belajar yang efektif, maka pendidikan hendaknya psikologis. Pendidikan psikologis dalam arti bahwa, berorientasi kepada sifat dan hakikat anak didik sebagai manusia yang berkembang. Pada dasarnya kegiatan atau perbuatan yang dilakukan setiap orang didasari oleh kecenderungan atau keinginan atau minat. Definisi minat adalah suka, rasa ketertarikan, perhatian, focus, ketekunan, pengetahuan dan keterampilan. Minat merupakan landasan penting bagi seseorang untuk melakukan kegiatan dengan baik. Sebagai suatu aspek kejiwaan minat bukan saja dapat mempengaruhi tingkah laku seseorang, tapi juga dapat mendorong orang untuk tetap melakukan dan memperoleh sesuatu. Keluarga mempunyai peran yang penting terhadap minat belajar anak dan keberhasilan belajar murid di sekolah, apabila keluarga khususnya orang tua bersifat merangsang, mendorong dan membimbing terhadap aktivitas belajar anaknya. Sebagaimana hasil penelitian Hero \& Sni (2018) bahwa melalui peran orang tua dalam belajar dapat menigkatkan motivasi belajar siswa. Terlihat dari prestasi belajar siswa yang semakin meningkat, terbukti dengan nilai-nilai yang diperoleh siswa lebih baik.

Keterlibatan orang tua memungkinkan diri anak untuk mempunyai minat belajar, lebih khususnya berminat pada pelajaran membaca dan umumnya mencapai prestasi belajar yang tinggi. Sebaliknya, bila orang tua acuh tak acuh terhadap aktivitas belajar anak, biasanya anak kurang atau tidak memiliki semangat belajar, sehingga, namun kenyataannya sebagian siswa cenderung kurang berminat pada saat pembelajaran membaca. Hal ini dapat dilihat dari seringnya anak-anak permisi keluar kelas pada saat tes membaca, seringnya anakanak ngobrol, dan ada beberapa anak yang suka bercerita dengan temen sebangkunya saat guru sedang menjelaskan tentang isi bacaan. Ini berdampak buruk bagi anak ketika anak tidak memiliki minat untuk belajar membaca baik disekolah maupun dirumah. Lalu, banyak orang tuanya yang hanya ingin anaknya memiliki nilai yang tinggi di sekolah tetapi orang tua tersebut tidak ikut berperan dalam kegiatan belajar anaknya dirumah sulit diharapkan ia dapat berminat terhadap belajar membaca dan sulit mencapai prestasi di sekolah secara maksimal. Seorang anak akan mempunyai minat yang lebih tinggi terhadap minat membaca, apabila orang tuanya memberikan pengertian dirumah dengan pembiasaan yang baik dalam kehidupan sehari-hari untuk dapat mengajarkan membaca pada anaknya.

Ada beberapa hal yang dapat mempengaruhi minat seseorang salah satunya adalah orang tua. Hal ini juga disebutkan di dalam buku Susanto (2016) mengatakan bahwa pembentukan minat belajar dapat dipengaruhi oleh lingkungan bermain, teman sebaya, pola asuh orang tua merupakan faktor yang dapat mempengaruhi minat seseorang. Kemudian agar minat baca siswa di sekolah baik, diperlukan usaha nyata yang dilakukan oleh para orang tua. Orang tua sebagai penanggung jawab utama pendidikan akan sangat besar peranannya dalam mengkontrol proses belajar anaknya. Bisa dikatakan salah satu faktor bahwa keberhasilan anak dalam meningkatkan kemampuan membaca anak adalah karena peran orang tuanya dalam mengontrol kegiatan belajar anaknya. Jika orang tua tidak berperan secara baik dan cenderung kurang peduli, maka kemungkinan anak tersebut akan mengalami masalah dalam belajar membaca dan tidak berminat dalam mengikuti kegiatan pembelajaran. Karena anak tersebut merasa kurang diperhatikan oleh orang tuanya sehingga anak tersebut kurang 
40 Lismayanti, M., Nurhayati, S., \& Rosita, T. Peran Orang Tua dalam Memotivasi Anak untuk Mengikuti Pembelajaran E-Learning (Online) dalam Rangka Meningkatkan Minat Baca pada Program Kesetaraan Paket C

berminat dalam mengikuti kegiatan belajar. Menurut Padmadewi, Artini, Nitiasih, \& Swandana (2018) melibatkan orang tua dalam meningkatkan minat baca anak juga memerlukan perhatian secara khusus. Perlu disesuaikan waktu, keahlian, pengalaman, dan ketersediaan serta komitmen orang tua dengan program literasi di sekolah.

Proses pembelajaran di sekolah selama ini selalu menempatkan anak sekolah sebagai obyek yang harus diisi oleh sejumlah ragam informasi dan sejumlah bahan-bahan ajar setumpuk lainnya. Terjadi komunikasi hanya satu arah yaitu antara guru ke anak siswa dengan membelajarkan melalui pendekatan ekspositori yang merupakan andalan dalam metode pembelajaran. Interaksi semacam ini sudah berlangsung lama dan berdampak verbalisme semakin merajalela. Pembelajaran semacam ini masih konvesional karena keterlibatan guru dengan siswa dalam satu ruang kelas dalam bentuk tatap muka langsung dan model ini dianggap hal yang amat penting. Sehingga secara tidak langsung kreativitas dan daya tarik (minat) belajar warga belajar telah dirampas, sekolah cenderung kurang terarah dikarenakan kurikulum yang tidak serasi, malahan sekolah cenderung bersifat menunggu perkembangan. Seiring dengan perkembangan teknologi terutama kemajuan teknologi komunikasi yang menyebabkan sistem penyampaian materi pelajaran dapat dilakukan tanpa harus tatap muka antara guru dengan siswa, akan tetapi bentuk belajar yang terpisah antara guru dengan siswa dilakukan bersamaan. Berbagai penerapan yang mungkin dapat digunakan antara lain jaringan HP, komputer, internet, laboratorium, dan lain-lain, pembelajaran dengan menggunakan teknologi sering disebut dengan Elektronic Leraning (E. Learning), sangat layak untuk diterapkan karena dapat memberikan beberapa bantuan yang sangat bermanfaat dalam pelaksanaan pembelajaran (Isjoni \& Ismail, 2008).

Manfaat yang dapat diambil adalah dapat meningkatkan minat baca anak, sebab, pada dasarnya pembelajaran $E$. Learning bukanlah pembelajaran yang hanya sebatas memperkenalkan teknologi semata kepada anak, tetapi membantu kepada guru untuk mengintegrasikan teknologi selama proses pembelajaran, bagaimana guru dapat mengaplikasikan kurikulum dalam pembelajaran. Selain itu, media dan sumber pembelajaran memainkan peranan yang sangat penting dalam proses pembelajaran. Penggunaan media dan bahan sumber $E$. Learning yang sesuai bukan saja dapat membantu penyampaian isi pelajaran, tetapi juga dapat menarik minat anak dalam mengikuti pembelajaran dan membuat anak menjadi tidak bosan. Oleh sebab itu, dia selalu haus bertanya, meminta bimbingan, serta menginginkan pendidikan. Untuk itu, peran orang tua sangat dibutuhkan dalam proses perkembangan anak. Lingkungan keluarga merupakan media pertama dan utama yang secara langsung atau tak langsung berpengaruh terhadap perilaku dalam perkembangan anak didik.

Tujuan pendidikan secara universal dapat dikatakan agar anak manusia tersebut menjadi mandiri, dalam arti bukan saja dapat mencari nafkahnya sendiri, namun juga mengarahkan dirinya berdasarkan keputusannya sendiri untuk mengembangkan semua kemampuan fisik, mental, sosial, dan emosional yang dimilikinya, sehingga dapat mengembangkan sesuatu kehidupan yang sehat dan produktif, dengan memiliki kepedulian terhadap orang lain. Untuk itu orang tua memegang peranan yang sangat penting dalam membimbing dan mendampingi anak dalam kehidupan keseharian anak. Sudah merupakan kewajiban para orang tua unntuk menciptakan lingkungan yang kondusif sehingga dapat memancing keluar potensi anak, kecerdasan dan rasa percaya diri. Dan tidak lupa memahami tahap perkembangan anak serta kebutuhan pengembangan potensi kecerdasan dari setiap anak. Media pembelajaran sangat penting dalam berlangsungnya proses pembelajaran, namun terdapat beberapa hambatan yang dapat mengganggu anak dalam berlangsungnya kegiatan pembelajaran yang baik, yaitu diantaranya mengenai keterbatasan ketidakmampuan dalam menggunakan media 
pembelajaran tersebut, dalam rangka mewujudkan tujuan tersebut, maka perlu adanya usaha yang harus dilakukan secara bertahap, karena meningkatkan membaca anak lebih rumit dibandingkan dengan proses komunikasi lisan.

\section{LANDASAN TEORI \\ Pembelajaran E-Learning}

E-Learning adalah singkatan dari electronic learning yang merupakan proses belajar mengajar dengan menggunakan media elektronik seoerti internet sebagai sistem pembelajarannya. (Komendangi, Molenaar, \& Lengkey, 2017). E-Learning merupakan suatu model pembelajaran yang dibuat secara digital melalui seperangkat elektronik. Pelaksanaanya dibagi menjadi dua yaitu dilaksanakan secara langsung yaitu instruktur memberikan materi secara langsung, dan dilaksanakan secara tidak langsung yaitu instruktur memberikan pembelajaran deng an rekaman materi (Tafiardi, 2005).

Effendi \& Zuang (2005) menyebutkan beberapa strategi dalam penyusunan pembelajaran elearning yaitu: 1) memperjelas tujuan pembelajaran yang akan dicapai, 2) mengetahui sumber daya yang dibutuhkan, 3) menyelaraskan tujuan bagi semua pihak yang terlibat dalam pembelajaran, dan 4) mengetahui indikator keberhasilan.

\section{Motivasi}

Menurut Gulo (2007) motivasi merupakan dorongan kuat dari dalam diri seseorang untuk melakukan sesuatu dengan cara-cara tertentu. Lebih lanjut Ibrahim, Siti Partini Suardiman Ibrahim \& Suardiman (2014) menyebutkan bahwa motivasi yang besar akan menjadikan seseorang yang tidak mampu menjadi mampu, yang tidak bisa menjadi bis, serta motivasi dalam belajar sangat penting untuk menunjang keberhasilan pendidikan. Menurut Uno (2011) motivasi belajar merupakan dorongan dari dalam dan luar pada siswa yang sedang belajar untuk melakukan suatu tingkah laku dengan insur-unsur yang mendukung seperti adanya keinginan berhasil, dorongan dan kebutuhan dalam belajar, harapan dan cita-cita masa depan, penghargaan dalam belajar, serta lingkungan belajar yang kondusif. Adapun fungsi motivasi menurut Hamalik (2011) meliputi: 1) mendorong timbulnya kelakukan atau suatu perbuatan, 2) sebagai pengarah dalam mencapai tujuan yang diinginkan, dan 3) sebagai penggerak dalam kegiatan belajar.

Motivasi merupakan kekuatan yang mendorong individu dalam melakukan aktivitas dalam memenuhi kebutuhan. Dengan demikian, setiap orang yang akan memberikan motivasi harus mengetahui dan memahami dengan seksama latar belakang kehidupan, kebutuhan, dan kepribadian orang yang akan dimotivasi (Rukanda, Nurhayati, \& Ganda, 2019).

\section{Peran Orang Tua}

Hamalik (2011) menjelaskan bahwa peran merupakan pola tingkah laku tertentu yang menjadi ciri dari semua petugas yang memiliki pekerjaan atau jabatan tertentu. Lestari (2011) Peran orang tua adalah cara-cara yang digunakan oleh orang tua yang berkaitan dengan pandangan mengenai tugas yang harus dijalankan dalam mengasuh anak. menurut Arifin (umar) ada tiga peran orang tua dalam prestasi anak di antaranya: 1) menyediakan kesempatak bagi anak untuk menemukan minat, bakat, dan kecakapan lainnya serta mendorong anak agar meminta bimbingan dan nasehat dari guru. 2) menyediakan indormasi penting dan relevan yang sesuai denagn bakat dan minat anak. 3) menyediakan fasilitas belajar dan membantu kesulitan anak dalam belajar. Sucipto dan Raflis (2000) menambahkan bahwa orang tua harus menjadi motivator bagi anak dalam belajar. Orang tua memberikan dorongan mengenai pentingnya belajar agar dapat meningktkan prestasi belajar, sehinga anak 
42 Lismayanti, M., Nurhayati, S., \& Rosita, T. Peran Orang Tua dalam Memotivasi Anak untuk Mengikuti Pembelajaran E-Learning (Online) dalam Rangka Meningkatkan Minat Baca pada Program Kesetaraan Paket C

benar-benar merasakan kebutuhan dan pentingnya belajar sebagaimana yang disampaikan orangtuannya.

\section{METODE PENELITIAN}

Penelitian ini dilakukan dengan metode deskriptif kualitatif yaitu dengan cara memandang objek penelitian sebagai suatu sistem, yaitu artinya objek kajian dapat dilihat sebagai satuan yang terdiri dari unsur yang saling terkait dan mendeskripsikan fenomena yang ada. Subjek penelitian ini adalah satu orang Guru/Tutor yang berinisial DA dan tiga orang (berinisial IS, CA dan HI) Peserta Didik Paket C PKBM Srikandi dari jumlah keseluruhan lima orang peserta didik. Penelitian dilaksanakan pada bulan januari 2020 sampai dengan bulan Mei 2020. Penelitian ini bersifat deskriptif berupa dokumen pribadi, catatan harian, catatan lapangan, ataupun ucapan responden dari hasil wawancara. Instrumen dalam penelitian ini yaitu peneliti sendiri yang dibantu oleh observasi, pedoman wawancara, dan studi dokumentasi. Teknik pengumpulan data yang digunakan adalah observasi, wawancara dan dokumentasi.

Tahapan analisis data dalam penelitian ini yaitu reduksi data, display data dan penarikan kesimpulan. Reduksi data dimaksudkan dengan merangkum data, memilih hal-hal pokok, disusun secara sistematik display data atau penyajian data bertujuan untuk memudahkan peneliti memahami hasil penelitian yang telah didapatkan. Data tersebut dibandingkan dan dihubungkan dengan yang lainnya, sehingga mudah ditarik kesimpulan sebagai jawaban dari setiap permasalahan yang ada.

\section{HASIL DAN PEMBAHASAN}

\section{Hasil}

Berdasarkan hasil wawancara dengan DA selaku Tutor di PKBM Srikandi, mengatakan bahwa pembelajaran E-learning diberikan kepada peserta didik agar mereka dapat perhatian lebih dari orang tua masing-masing. Selain itu orang tua harus memantau, mengawasi dan membimbing serta memberikan motivasi kepada anaknya supaya minat belajarnya meningkat terutama minat baca peserta didik. Orang tua diharuskan berperan aktif selama pembelajaran online dengan peserta didik. Kemudian orang tua harus memberikan laporan perkembangan anaknya selama pembelajaran online. Kemudian peneliti melakukan wawancara kepada peserta didik PKBM Srikandi, IS mengatakan selama pembelajaran online selalu ditemani oleh orang tua, meskipun sebentar rasanya sudah senang, sebelumnya orang tua sibuk dengan pekerjaannya, namun setelah dilaksanakannya pembelajaran online orang tua harus berperan dalam belajar. Dengan ditemani orang tua semangat belajar saya pun meningkat, meskipun pada awalnya sih malu kenapa sih harus ditemani orang tua, kan kami sudah besar, ternyata yang saya pikirkan itu salah, ternyata saat saya berdiskusi dengan orang tua banyak wawasan dan pengetahuan yang saya dapatkan dari orang tua.

Pendapat lain diungkapkan oleh CA yang mengatakan bagi saya sih belajar dengan orang tua belum terbiasa, karena sebelumnya saya paling belajar dengan kawan-kawan, tapi lama kelamaan sudah biasa, belajar didampingi orang tua serasa ditemani teman ternyata menyenangkan. Selain itu saya juga sering berbagi cerita sama orang tua terlebih tentang pelajaran dan pengalaman. Sedangkan HI berbendapat bahwa pembelajaran e-learning membuat saya merasa senang bisa diperhatikan orang tua, apalagi ketika berbagi cerita dengan orang tua. Ya meskipun waktu yang diberikan orang tua enggak terlalu banyak, tapi belajar dengan orang tua membuat semangat belajar kita naik. Biasanya saya malas dalam mengerjakan tugas yang diberikan tutor, tapi setelah banyak nya motivasi yang diberikan 
orang tua mewmbuat saya sadar kalau belajar itu penting untuk menambah pengetahuan dan wawasan saya. Selain itu materi-materi yang diberikan oleh tutor juga tidak terlalu sulit, kebanyakan materi kita berdiskusi dengan orang tua mengenai permasalah-permasalahan yang terjadi dimasyarakat.

Berdasarkan pengamatan dilapangan, didapatkan data mengenai perencanaan orang tua dalam memotivasi anak untuk mengikuti pembelajaran e-learning (online) bahwa peran orang tua sangatlah penting bagi seorang anak, terutama dalam hal segi pendidikan, oleh karena itu PKBM melibatkaan orang tua dalam pembelajaran untuk memotivasi anaknya, dimulai dari merumuskan tujuan pembelajaran yang disesuaikan dengan kebutuhan peserta didik. Kegiatan ini diselengarakan dalam rangka untuk memberi motivasi belajar terhadap anak, terutama dalam pembelajaran e-learning, agar peserta didik memiliki kemampuan pendidikan untuk mengembangkan potensi dirinya.

Pelaksanaan orang tua dalam memotivasi anak untuk mengikuti pembelajaran e-learning (online) dalam rangka meningkatkan minat baca pada program kesetaraan paket c di pkbm srikandi kota cimahi mengacu kepada kebutuhan peserta didik, terdiri dari kegiatan pendahuluan, inti, dan penutup. Pelaksanaan adalah penerapan dari perencanaan yang telah disusun sebelumnya dan pelaksanaan merupakan salah satu faktor yang menentukan keberhasilan dari suatu program atau kegiatan. Pemberian materi yang diberikan berupa diskusi dengan orang tua, serta materi tugas individu untuk mengembangkan pengetahuan dan wawasan dari peseerta didik.

Hasil Orang Tua dalam Memotivasi Anak untuk Mengikuti Pembelajaran E-Learning (Online) dalam rangka Meningkatkan Minat Baca pada Program Kesetaraan Paket C di PKBM Srikandi Kota Cimahi mengacu pada standar kompetensi lulusan yang meliputi pengetahuan, sikap dan keterampilan, berkenaan dengan meningkatkan pendidikan peserta didik setelah adanya peran orang tua dalam pembelajaran, maka peserta didik akan lebih terpacu dalam menjalani pembelajaran untuk bekal hidupnya di masa yang akan datang

\section{Pembahasan}

Pembahasan ini menguraikan hasil penelitian mengenai Peran Orang Tua dalam Memotivasi Anak untuk Mengikuti Pembelajaran E-Learning (Online) dalam rangka Meningkatkan Minat Baca pada Program Kesetaraan Paket C di PKBM Srikandi. Berdasarkan hasil penelitian, kegiatan ini dimaksudkan untuk mengetahui peran orang tua kepada peserta didik terhadap pendidikan yang dijalaninya. Munandar (2013) menjelaskan tentang berbagai hal yang terkait dengan peranan orang tua dan lingkungan keluarga dalam mengembangkan potensi anak. Beberapa faktor lingkungan keluarga yang mempengaruhi pertumbuhan dan perkembangan anak. Masa yang tepat untuk memunculkan bakat-bakat itu. Jika anak didukung sejalan dengan kecenderungan alaminya, dia akan mengembangkan bakatnya itu dan menjadi orang yang berhasil. Orangtua sebaiknya mampu melihat beberapa kelebihan atau bakat terpendam pada anak nya. Orang tua hendaknya lebih memfokuskan perhatian pada kelebihan yang dimiliki anak dan mengarahkannya ke arah yang tepat.

Pada pengamatan awal, kegiatan pembelajaran dilakukan secara tatap muka langsung dengan peserta didik, namun setelah diberlakukannya Social Distancing kegiatan pembelajaran dilakukan secara Electronic Learning (Online). E. Learning pada hakikatnya adalah belajar atau pembelajaran melalui pemanfaatan teknologi komputer atau internet. Teknologi pembelajaran seperti itu juga dapat disebut pembelajaran berbasis web (Web Based Instuction) (Sa'ud, 2011). Pada perencanyaannya, orang tua dilibatkan dalam kegiatan 
44 Lismayanti, M., Nurhayati, S., \& Rosita, T. Peran Orang Tua dalam Memotivasi Anak untuk Mengikuti Pembelajaran E-Learning (Online) dalam Rangka Meningkatkan Minat Baca pada Program Kesetaraan Paket C

E.Learning untuk meningkatkan motivasi belajar anak. Seperti pendapat Susanto (2016) mengatakan bahwa pembentukan minat belajar dapat dipengaruhi oleh lingkungan bermain, teman sebaya, pola asuh orang tua merupakan faktor yang dapat mempengaruhi minat seseorang. Kemudian agar minat baca siswa di sekolah baik, diperlukan usaha nyata yang dilakukan oleh para orang tua. Orang tua sebagai penanggung jawab utama pendidikan akan sangat besar peranannya dalam mengkontrol proses belajar anaknya.

Pada observasi selanjutnya, pelaksanaan peran orang tua dalam memotivasi anak untuk mengikuti pembelajaran online mengacu kepada kebutuhan peserta didik, terdiri dari kegiatan pendahuluan, inti, dan penutup. Materi yang diberikan tutor berupa diskusi dengan orang tua, serta materi tugas individu untuk mengembangkan pengetahuan dan wawasan dari peseerta didik. Menurut Sudjana (2010), Belajar adalah suatu proses yang ditandai dengan adanya perubahan pada diri seseorang. Perubahan dalam diri seseorang dapat ditunjukkan dalam berbagai bentuk seperti berubahnya pengetahuannya, pemahamannya, sikap dan tingkah lakunya, keterampilan dan kemampuannya, daya reaksinya, daya penerimaannya dan lainlain aspek yang ada pada individu.

Sedangkan hasil kegiatan orang tua dalam memotivasi anak untuk mengikuti pembelajaran $e$ learning berupa tiga aspek yang meliputi pengetahuan, sikap dan keterampilan yang mengacu pada standar kompetensi lulusan sekaligus. Pembelajaran e-learning (online) dalam rangka meningkatkan minat baca pada program kesetaraan paket $\mathrm{C}$ dapat meningkatkan kecakapan hidup warga belajar mencakup kecakapan personal yaitu saling membantu, kecakapan sosial yaitu kemampuan untuk berinteraksi, berkomunikasi dengan teman sejawat, sedangkan kecakapan vokasional yaitu mempunyai lembaga pendidikan. Seperti hasil penelitian Hero \& Sni (2018) bahwa melalui peran orang tua dalam belajar dapat menigkatkan motivasi belajar siswa. Terlihat dari prestasi belajar siswa yang semakin meningkat, terbukti dengan nilai-nilai yang diperoleh siswa lebih baik.

\section{KESIMPULAN}

Peran orang tua dalam memotivasi anak untuk mengikuti pembelajaran e-learning (online) dalam rangka meningkatkan minat baca pada program kesetaraan paket $\mathrm{C}$ di pkbm srikandi kota cimahi, dilakukan melalui tiga tahapan, yaitu : perencanaan, pelaksanaan, dan hasil kegiatan, hasil kegiatan orang tua dalam memotivasi anak untuk mengikuti pembelajaran elearning, berupa tiga aspek yang meliputi pengetahuan, sikap dan keterampilan yang mengacu pada standar kompetensi lulusan sekaligus. Pembelajaran e-learning (online) dalam rangka meningkatkan minat baca pada program kesetaraan paket $\mathrm{C}$ dapat meningkatkan kecakapan hidup warga belajar mencakup kecakapan personal yaitu saling membantu, kecakapan sosial yaitu kemampuan untuk berinteraksi, berkomunikasi dengan teman sejawat, sedangkan kecakapan vokasional yaitu mempunyai lembaga pendidikan.

\section{DAFTAR PUSTAKA}

Effendi, E., \& Zuang, H. (2005). E-learning Konsep dan Aplikasi. Yogyakarta: Penerbit Andi.

Gulo, W. (2007). Metodologi penelitian cetakan ke-7. Jakarta: PT. Grasindo.

Hamalik, O. (2011). Proses Belajar Mengajar. Jakarta: Bumi Aksara.

Hero, H., \& Sni, M. E. (2018). Peran Orang Tua Dalam Meningkatkan Motivasi Belajar Siswa Kelas V Di Sekolah Dasar Inpres Iligetang. RPD (Jurnal Riset Pendidikan Dasar), 1(2), 129-139. 
Isjoni, \& Ismail. (2008). Model-Model Pembelajaran Mutakhir Perpaduan. Yogyakarta: Pustaka Pelajar.

Komendangi, F. K., Molenaar, R., \& Lengkey, L. (2017). NALISIS DAN PERANCANGAN APLIKASI E-LEARNING BERBASIS LEARNING MANAGEMENT SYSTEM (LMS) MOODLE DI PROGRAM STUDI TEKNIK PERTANIAN UNIVERSITAS SAM RATULANGI. COCOS, 1(3).

Munandar. (2013). Peran Keluarga dalam Pendidikan Anak. Bandung: Tarsito.

Rukanda, N., Nurhayati, S., \& Ganda. (2019). THE INFLUENCE OF STUDENTS' MOTIVATION ON ENTREPRENEURSHIP ATTITUDE. EMPOWERMENT: Jurnal Ilmiah Program Studi Pendidikan Luar Sekolah, 9(1), 47-65.

Sa’ud. (2011). Pembelajaran e-learning. Jakarta: Gunung Agung.

Sucipto, \& Raflis. (2000). Profesi Keorangtuaan. Jakarta: Rineka Cipta.

Sudjana, D. (2010). Manajemen Program Pendidikan untuk pengembangan Sumber Daya Manusia. Bandung: Falah Production.

Susanto, A. (2016). Teori Belajar dan Pembelajaran di Sekolah Dasar. Jakarta: Kencana Prenada Media Group.

Tafiardi. (2005). Meningkatkan mutu pendidikan melalui e-learning. Jurnal Pendidikan Penabur(4).

Uno, H. B. (2011). Teori Motivasi dan Pengukurannya: Analisis di Bidang . Jakarta: Bumi Aksara. 